\title{
Factors Associated With Successful Mobilization and Collection of Peripheral Blood Hematopoietic Stem Cells in Autologous and Allogeneic Donors
}

\author{
Rada M. Grubovic ${ }^{1 *}$, Borce Georgievski ${ }^{2}$, Lidija Cevreska ${ }^{2}$, Sonja Genadieva-Stavric ${ }^{2}$, Milos R. Grubovic $^{1}$ \\ ${ }^{1}$ Institute for Transfusion Medicine of RM, Medical Faculty, Ss. Cyril and Methodius University, Skopje, Republic of \\ Macedonia; ${ }^{2}$ University Clinic of Hematology, Medical Faculty, Ss. Cyril and Methodius University, Skopje, Republic of
} Macedonia

\begin{abstract}
Citation: Grubovic R, Georgievski B, Cevreska L, Genadieva-Stavric S, Grubovic MR. Factors Associated Blood Hematopoietic Stem Cells in Autologous and Allogeneic Donors. SEE J Immunol. 2017 Dec 26; 2017:20012. https://doi.org/10.3889/seejim.2017.20012 Keywords: peripheral blood stem cells; hematopoietic stem cells; apheresis collection; mobilization strategy; stem cell harvesting.

'Correspondence: Rada M. Grubovic, MD MSci. Institute for Transfusion Medicine of RM. Medical Faculty, Ss. Cyri and Methodius University, 1000 Skopje, Republic of Macedonia. E-mail: rgrubovic@yahoo.com

Received: 23-Oct-2017; Revised: 08-Nov-2017; Accepted: 10-Nov-2017; Published: 26-Dec-2017

Copyright: ๑ 2017 Rada M. Grubovic, Borce Georgievski, Lidija Cevreska, Sonja Genadieva-Stavric distributed under the terms of the Creative Common Attribution-NonCommercial 4.0 International License (CC BY-NC 4.0).

Funding: This research did not receive any financia support.

Competing Interests: The author has declared that no competing interests exist.
\end{abstract}

\begin{abstract}
BACKGROUND: Peripheral blood hematopoietic stem cells (PBSC) have largely replaced bone marrow derived stem cells in autologous transplantations, and have become the preferred source of stem cells in the majority of allogeneic transplantations. Sufficient number of mobilized and collected hematopoietic stem cells (HSC) is needed for successful hematopoietic stem cell transplantation.
\end{abstract}

MATERIAL AND METHOD: This study was performed in the Institute for Transfusion Medicine of RM and the University Clinic of Hematology from 2008 till 2016. There were 30 allogeneic and 90 autologous donors that underwent mobilization and collection of PBSC. The association between possible predictive factors such as demographic characteristics, laboratory parameters and collection parameters in both groups, and mobilization strategy and clinical characteristics in autologous donors and number of collected PBSC was analyzed.

RESULTS: There were 226 apheresis, 182 in autologous donors (mean 2, range 1-3) and 44 apheresis in 30 allogeneic donors (mean 1.5, range 1-2). The mean number of collected MNC in autologous donors was $3.09 \times 10^{8} / \mathrm{kg}$ and $2.85 \times 10^{6} / \mathrm{kg}$ CD34+ cells, and $3.23 \times 10^{8} / \mathrm{kg} \mathrm{MNC}$ and $3.20 \times 10^{6} / \mathrm{kg}$ CD34+ cells in allogeneic donors. Significantly larger number of MNC and CD34+ cells was collected with the WBC set. There was a statistically significant correlation between the total number of collected MNC in autologous donors and platelet count before mobilization, the number of cycles in one apheresis procedure, quantity of collected graft and the number of collected MNC and CD34+ cells on the first day of harvestration. There was a statistically significant correlation between the total number of collected MNC in allogeneic donors and platelet count before mobilization, the number of cycles in one apheresis procedure, quantity of collected graft and number of MNC on first day of harvestration. There was a strong correlation between the number of collected MNC and CD34+ cells on the first harvest and the total number of collected MNC and CD34+ cells in poor mobilizers, and inverse correlation with the number of apheresis procedures. Donors who donated MNC $\leq 0.7 \times 10^{8} / \mathrm{kg}$ and $/ \mathrm{or} \leq 0.7 \times 10^{6} / \mathrm{kg}$ CD34+ cells on the first harvest $(84.6 \%)$ were strong predictors of poor mobilizers.

CONCLUSION: Determining the proper level of baseline and preaheresis laboratory parameters for initiating mobilization and apheresis procedure which is safe for donors and greatly efficient in collection of PBSC is needed for optimization of these procedures, as well as for early intervention in poor mobilizers

\section{Introduction}

Hematopoietic stem cells transplantation (HSCT) has been used as a curative treatment in variety of congenital and acquired hematological and non-hematological benign and malign diseases [1-8]. Transplantation of peripheral blood stem cells (PBSC) provides complete and long-term reconstitution of the hematopoietic system of the patients and may result in remission or cure in a proportion of cases [8-9]. Given the numerous advantages such as, lower rates of morbidity and mortality, shorter hospitalization, lower costs of treatment and the possibility of applying high-dose chemotherapy to an older group of patients, mobilized peripheral blood stem cells have largely replaced the use of bone marrow derived stem cells as the preferred source of hematopoietic stem cells in autologous and allogeneic transplantation [1, 4, 8-13]. There is no consensus on the amount of progenitor 
cells to be infused to achieve adequate cell recovery yet. However, a minimum of $2-5 \times 10^{6}$ CD34+ cells per kilogram in adults have shown good results [14, 15]. Worldwide $99 \%$ of autologous hematopoietic stem cell transplantations and $75 \%$ of allogeneic are performed with PBSC. Progenitor stem cells are rare and they primarily reside in the bone marrow and in extreme small amounts $(0.01-0.5 \%$ nucleated cells) in the peripheral blood [16, 17].

Mobilization of these cells in the peripheral blood with growth factors only or in combination with chemotherapy results in multiplying the number of circulating hematopoietic stem cells, makes it easier to be harvested from the peripheral blood [17, 18]. Proper timing of collection of PBSC following mobilization is crucial for maximization of harvest. Few different parameters were investigated as possible predictive factors for apheresis harvest, such as number of platelets [4, 19, 20], total leukocyte count [20], lymphocyte count [20], monocyte count $(20,21)$ and percentage of circulating immature granulocytes [22]. Number of CD34+ cells in the peripheral blood is accepted as best indicator for initiation of apheresis. Although the technics used for calculating the number of CD34+ cells are highly specialized and expensive, they are not universally available and it takes longer to obtain results [20, 2327]. Therefore, parameters that are more available were investigated as potential predictive factors. It is still not clear which protocol is optimal for maximal harvesting of PBSC.

The aim of this study is to analyze the association between the mobilized and collected PBSC and possible predictive factors, such as demographic characteristics, laboratory parameters and collection parameters in both autologous and allogeneic donors and the mobilization strategy and clinical characteristics in autologous donors.

\section{Material and Methods}

This is a retrospective-prospective study performed in the Institute for Transfusion Medicine of RM and the University Clinic of Hematology in Skopje, Macedonia from 2008 till 2016. The investigated group consisted of 90 autologous donors/hematologic patients - 30 patients diagnosed with acute myeloid leukemia $(A M L), 30$ with lymphoma and 30 with multiple myeloma (MM), and 30 allogeneic donors. The study was approved by the Ethical Committee for Biomedical Research at Medical Faculty in Skopje. All subjects in the study gave their written consent for performing the research, mobilizing strategy, apheresis collection of peripheral blood hematopoietic stem cells, cryopreservation and transplantation (according to Recommendations of WMA Revision of Declaration of Helsinki). Mobilization of PBSC was performed with the granulocyte colony-stimulating factor (G-CSF) $10 \mu \mathrm{cg} / \mathrm{kg} /$ day (as single mobilizing strategy) or in combination of G-CSF + chemotherapy depending on diagnosis and disease status. The collection of PBSC was performed by the apheresis procedure with the cellular separator COBE Spectra Version 6.1 (TerumoBCT) in the Institute for Transfusion Medicine of RM. Collection target was $\geq 2 \times 10^{8} / \mathrm{kg} \mathrm{MNC}$ and $/$ or $\geq 2 \times 10^{6} / \mathrm{kg} \mathrm{CD} 34+$ cells during the first three days of apheresis. The following parameters were analyzed: demographic characteristics, laboratory parameters and collection parameters in both autologous and allogeneic donors; and the mobilization strategy and clinical characteristics in autologous donors.

Table 1: Characteristics of autologous and allogeneic donors

\begin{tabular}{|c|c|c|c|}
\hline Donors characteristics & $\begin{array}{l}\text { Autologous } \\
\text { (Number / \%) }\end{array}$ & $\begin{array}{c}\text { Allogeneic } \\
\text { (Number /\%) }\end{array}$ & $p<0.05$ \\
\hline \multicolumn{4}{|l|}{ Gender } \\
\hline Male & $56(62.2 \%)$ & $21(70.0 \%)$ & \\
\hline Female & $34(37.8 \%)$ & $9(30.0 \%)$ & \\
\hline \multicolumn{4}{|l|}{ Age } \\
\hline (mean, range) & $45 \pm 13.0(18-65)$ & $34.3 \pm 12.2(19-63)$ & \\
\hline$<20$ & $3(3.4 \%)$ & $2(6.7 \%)$ & \\
\hline $20-29$ & $11(12.2 \%)$ & $12(40.0 \%)$ & \\
\hline $30-39$ & $15(16.7 \%)$ & $4(13.3 \%)$ & \\
\hline $40-49$ & $21(23.3 \%)$ & $7(23.3 \%)$ & \\
\hline $50-59$ & $31(34.4 \%)$ & $5(16.7 \%)$ & \\
\hline$>=60$ & $9(10.0 \%)$ & / & \\
\hline Weight (kg) & $78.5 \pm 15.5(51-136)$ & $75.9 \pm 14.1(56-105)$ & \\
\hline \multicolumn{4}{|l|}{ (mean, range) } \\
\hline Height $(\mathrm{cm})$ & $170.8 \pm 9.6$ & $173.8 \pm 7.1$ & \\
\hline (mean, range) & $(150-190)$ & $(160-190)$ & \\
\hline \multicolumn{4}{|l|}{ ABO blood type } \\
\hline $\mathrm{O}_{+}$ & $33(36.7 \%)$ & $13(43.3 \%)$ & \\
\hline$O-$ & $4(4.4 \%)$ & 1 & \\
\hline$A_{+}$ & $25(27.8 \%)$ & $8(26.7 \%)$ & \\
\hline$A-$ & $3(3.3 \%)$ & 1 & \\
\hline$B+$ & $18(20 \%)$ & $3(10.0 \%)$ & \\
\hline$B-$ & $2(2.2 \%)$ & $3(10.0 \%)$ & \\
\hline$A B+$ & $5(5.6 \%)$ & $1(3.3 \%)$ & \\
\hline$A B-$ & $1(1.1 \%)$ & $1(3.3 \%)$ & \\
\hline \multicolumn{4}{|l|}{$\begin{array}{l}\text { Parameters before } \\
\text { mobilization (mean, } \\
\text { range) }\end{array}$} \\
\hline WBC $\left(\times 10^{9} / I\right)$ & $5.6 \pm 2.3(1.9-14.1)$ & $8.1 \pm 5.6(3.9-29.1)$ & $\mathrm{p}=0.001198$ \\
\hline$H g b(g / d l)$ & $12.1 \pm 1.7(8-15.5)$ & $14.7 \pm 1.5(11.8-18)$ & $\mathrm{p}=0.000000$ \\
\hline Plt $\left(x 10^{9} / /\right)$ & $254 \pm 117.0(78-649)$ & $216 \pm 46.0(130-306)$ & NS \\
\hline \multicolumn{4}{|l|}{$\begin{array}{l}\text { harvestration (mean, } \\
\text { range) }\end{array}$} \\
\hline WBC $\left(\times 10^{9} / I\right)$ & $21.5 \pm 12.6(2.95-61.8)$ & $29.6 \pm 8.2(13.3-42.8)$ & $\mathrm{p}=0.000170$ \\
\hline$H g b(g / d)$ & $12.0 \pm 1.3(9.7-16)$ & $14.4 \pm 1.5(11.1-17.5)$ & $\mathrm{p}=0.000000$ \\
\hline Plt $\left(x 10^{9} / 1\right)$ & $167.9 \pm 95.0(40-381)$ & $201.2 \pm 61.2(140-305)$ & $\mathrm{p}=0.032651$ \\
\hline $\mathrm{Hct}(\%)$ & $36.0 \pm 4.3(15.6-48)$ & $43.6 \pm 3.9(36.1-49.7)$ & $\mathrm{p}=0.000000$ \\
\hline$R B C\left(\times 10^{9} / /\right)$ & $3.9 \pm 0.5(3.1-7.73)$ & $4.8 \pm 0.4(3.98-5.7)$ & $\mathrm{p}=0.000000$ \\
\hline Monocytes (\%) & $9.7 \pm 4.9(1.3-25.1)$ & $5.4 \pm 2.4(1.4-10.5)$ & $\mathrm{p}=0.000001$ \\
\hline Lymphocytes (\%) & $12.2 \pm 6.1(3.2-28.8)$ & $11.8 \pm 3.5(6.6-20.6)$ & NS \\
\hline LymMon (\%) & $21.8 \pm 9.4(7-53)$ & $17.5 \pm 4.5(10-26)$ & $p=0.027808$ \\
\hline \multicolumn{4}{|l|}{ Transfusion before } \\
\hline \multirow{2}{*}{\multicolumn{4}{|c|}{ harvestration (number }} \\
\hline \multirow{2}{*}{\multicolumn{4}{|c|}{$\begin{array}{l}\text { of units, mean, range) } \\
\text { Erythrocyte }\end{array}$}} \\
\hline & $21(23.3 \%)$ & & \\
\hline $\begin{array}{l}\text { Erythrocyte } \\
\text { transfusion }\end{array}$ & $3.8 \pm 2.8(1-11)$ & & \\
\hline \multirow{2}{*}{$\begin{array}{l}\text { Platelet transfusion } \\
\text { (RD) }\end{array}$} & & I & \\
\hline & $\begin{array}{c}20(22 \%) \\
16.176(1-66)\end{array}$ & & \\
\hline \multirow{2}{*}{$\begin{array}{l}\text { Platelet transfusion } \\
\text { (SD) }\end{array}$} & & / & \\
\hline & $\begin{array}{c}7(7.8 \%) \\
\quad(1-2)\end{array}$ & & \\
\hline \multicolumn{4}{|l|}{ Mobilization strategy } \\
\hline G-CSF & 64 (71.1\%) & $30(100 \%)$ & \\
\hline G- & $26(28.9 \%)$ & 1 & \\
\hline \multicolumn{4}{|l|}{$\begin{array}{l}\text { CSF+chemotherapy } \\
\text { Adverse events }\end{array}$} \\
\hline $\begin{array}{l}\text { Yes } \\
\text { No }\end{array}$ & $\begin{array}{l}14.4 \% \\
85.6 \%\end{array}$ & $\begin{array}{l}43.3 \% \\
56.7 \%\end{array}$ & $\mathrm{p}=0.0009$ \\
\hline
\end{tabular}

\section{Statistical analysis}

Statistical analysis was done in the statistical program Statistica 7.1 and SPSS 17.0. The following 
methods were used in this study: the percentage of structure (\%) was determined in series with attributive marks; descriptive statistics (Mean \pm S.D., Minimum, Maximum, Median) was used in series with numerical marks; differences between the autologous and allogeneic donors in the parameters with attributive and numerical marks were tested with Mann-Whitney $U$ test. The association between the investigated variables and the number of collected mononuclear cells (MNC) was assessed with Spearman rank order correlation. The accepted level of significance was $p<$ 0.05 .

\section{Results}

Donors' characteristics and laboratory parameters of autologous and allogeneic donors are shown in Table 1.

Clinical characteristics of autologous donors are shown in Table 2.

\section{Table 2: Clinical characteristics of autologous donors}

\begin{tabular}{|c|c|}
\hline Clinical characteristic of autologous donors & Number (\%) \\
\hline \multicolumn{2}{|l|}{ Diagnosis } \\
\hline AML & $30(33.3 \%)$ \\
\hline MM & 30 (33.3\%) \\
\hline $\mathrm{HD}$ & $19(21.1 \%)$ \\
\hline $\mathrm{NHL}$ & $11(12.3 \%)$ \\
\hline \multicolumn{2}{|l|}{ Disease stadium } \\
\hline $\mathrm{CR}$ & $46(51.1 \%)$ \\
\hline PR & $23(25.6 \%)$ \\
\hline Active disease (relapse) & $21(23.3 \%)$ \\
\hline \multicolumn{2}{|l|}{ Chemotherapy cycles } \\
\hline 0 & 1 \\
\hline $1-4$ & $45(50 \%)$ \\
\hline $5-8$ & $21(23.3 \%)$ \\
\hline 9-12 & $13(14.4 \%)$ \\
\hline $13-16$ & $7(7.8 \%)$ \\
\hline$\geq 17$ & $4(4.4 \%)$ \\
\hline \multicolumn{2}{|l|}{ Previous radiotherapy and/or HSCT } \\
\hline Radiotherapy+HSCT & $2(2.2 \%)$ \\
\hline Radiotherapy & $12(13.3 \%)$ \\
\hline HSCT & $7(7.8 \%)$ \\
\hline No radiotherapy and/or HSCT & $69(76.7 \%)$ \\
\hline \multicolumn{2}{|l|}{$\begin{array}{l}\text { Period from diagnosis to harvestration (months) - mean, } \\
\text { range }\end{array}$} \\
\hline $\begin{array}{l}\text { AML-acute myeloid leukemia, MM-multiple myeloma, } \\
\text { Hodgkin lymphoma, AA-aplastic anemia, ALL-acute } \\
\text { myelofibrosis, CML-chronic myeloid leukemia, CR-c }\end{array}$ & $\begin{array}{l}\text { dgkin disease, NHL-non- } \\
\text { hoblastic leukemia, MF- } \\
\text { te remission, PR-partial }\end{array}$ \\
\hline
\end{tabular}

There were 226 apheresis procedures, 182 performed in 90 autologous donors and 44 procedures performed in 30 allogeneic donors. The mean number of apheresis procedures in autologous donors was $2.0 \pm 0.6$ (range 1-3) and $1.5 \pm 0.5$ (range 1-2) in allogeneic with significant difference between two of them $(p<0.05)$. Seventy six autologous donors $(66.7 \%)$ had two apheresis procedures, sixteen autologous donors (17.7\%) had three procedures and fourteen autologous donors (15.6\%) had one procedure, while eight allogeneic donors (53.3\%) had one procedure and twenty two allogeneic donors $(46.7 \%)$ had two procedures. All donors tolerated well mobilization and collection procedures, with minor side effects in $14.4 \%$ of autologous and $43.3 \%$ allogeneic donors. The mean number of collected
MNC in autologous donors was $3.09 \pm 1.1$ (range 0.86.2 ) and $3.23 \pm 1.03$ (range 2.0-7.3) in allogeneic, respectively. There was not a statistically significant difference between the number of collected MNC in autologous and allogeneic donors for $\mathrm{p}>0.05$ (MannWhitney $U$ test $Z=-0.46364, p=0.642909)$. The mean number of collected CD34+ cells in autologous donors was $2.85 \pm 1.1$ (range 0.7-5.9) and 3.20 \pm 1.01 (range 2.0-7.3) in allogeneic. There was not a statistically significant difference between the number of collected CD34+ cells in autologous and allogeneic donors for $p>0.05$ (Mann-Whitney $U$ test $Z=$ $-1.53091, p=0.111631)$. Characteristics of PBSC collection are shown in Table 3.

Table 3: Characteristics of PBSC collection

\begin{tabular}{lcc}
\hline Characteristics of PBSC collection & Autologous donors & Allogeneic donors \\
\hline No. of apheresis procedures & 182 & 44 \\
No. of procedures per donor & 2.0 & 1.5 \\
No. of donors collecting $<2 \times 10^{8} / \mathrm{kg} \mathrm{MNC}$ & $13(14.4 \%)$ & $/$ \\
No. of donors collecting $\geq 2 \times 10^{8} / \mathrm{kg} \mathrm{MNC}$ & $77(85.6 \%)$ & $30(100 \%)$ \\
$\quad$ with 1 apheresis & $14(15.6 \%)$ & $16(53.3 \%)$ \\
$\quad$ with 2 apheresis & $60(66.7 \%)$ & $14(46.7 \%)$ \\
$\quad$ with 3 apheresis & $16(17.7 \%)$ & $/$ \\
Type of set used for apheresis & $34.1 \%$ & \\
$\quad$ WBC set & $65.9 \%$ & $22.7 \%$ \\
$\quad$ AutoPBSC & $3.09(0.8-6.2)$ & $3.23(2.0-7.3)$ \\
No. of collected MNC $\times 10^{8} / \mathrm{kg}$ - total & $1.7(0.2-5.8)$ & $2.4(0.7-4.8)$ \\
(mean, range) & $1.5(0.14-3.9)$ & $1.7(0.4-5.0)$ \\
1 apheresis & $1.1(0.2-3.7)$ & $/$ \\
2 apheresis & & \\
3 apheresis & $2.85(0.7-5.9)$ & $3.20(2.0-7.3)$ \\
No. of collected CD34+ cells $\times 10^{6} / \mathrm{kg}-$ & $1.6(0.2-5.5)$ & $2.3(0.6-3.9)$ \\
total (mean, range) & $1.3(0.14-3.7)$ & $1.6(0.4-4.8)$ \\
$\quad 1$ apheresis & $1.0(0.2-3.4)$ & $/$ \\
2 apheresis & 9475.6 & 9502.3 \\
$\quad 3$ apheresis & & \\
Total processed volume (ml) & &
\end{tabular}

All allogeneic donors (100\%) and 77 (85.6\%) autologous donors donated the wanted number of MNC and CD34+ cells. There were 13 autologous donors $(14.4 \%)$ who could be marked as poor mobilizers, of which 11 donors $(84.6 \%)$ had less than $\leq 0.70 \times 10^{8} / \mathrm{kg}$ MNC yield on the first day of harvestration (Table 4).

Table 4: Number of collected MNC - 1 day yield and total number of collected MNC $<2 \times 10^{8} / \mathrm{kg}$

\begin{tabular}{lccc}
\hline $\begin{array}{l}\text { Autologous donors } \\
\text { Number of collected MNC } \\
-1 \text { day yield }\end{array}$ & $\begin{array}{c}\text { Number of } \\
\text { donors }\end{array}$ & $\%$ & $\begin{array}{c}\text { Total number of MNC }< \\
2 \times 10^{8} / \mathrm{kg} \\
\text { Number of donors/(\%) }\end{array}$ \\
\hline$\leq 0.70 \times 10^{8} / \mathrm{kg}$ & 19 & 21.1 & $11(84.6 \%)$ \\
$0.71-1.40 \times 10^{8} / \mathrm{kg}$ & 18 & 20.0 & $2(15.4 \%)$ \\
$1.41-1.99 \times 10^{8} / \mathrm{kg}$ & 20 & 22.2 & $/$ \\
$2.00-2.99 \times 10^{8} / \mathrm{kg}$ & 21 & 23.3 & $/$ \\
$3.00-3.99 \times 10^{8} / \mathrm{kg}$ & 10 & 11.1 & $/$ \\
$\geq 4 \times 10^{8} / \mathrm{kg}$ & 2 & 2.2 & $/$ \\
Allogeneic donors & & & $/$ \\
$\leq 0.70 \times 10^{8} / \mathrm{kg}$ & 1 & 3.3 & $/$ \\
$0.71-1.40 \times 10^{8} / \mathrm{kg}$ & 5 & 16.7 & $/$ \\
$1.41-1.99 \times 10^{8} / \mathrm{kg}$ & 4 & 13.3 & $/$ \\
$2.00-2.99 \times 10^{8} / \mathrm{kg}$ & 12 & 40 & \\
$3.00-3.99 \times 10^{8} / \mathrm{kg}$ & 7 & 23.3 & \\
$\geq 4 \times 10^{8} / \mathrm{kg}$ & 1 & 3.3 & \\
\hline
\end{tabular}

Poor mobilizers were defined as donors that could not donate $\geq 2 \times 10^{8} / \mathrm{kg}$ MNC and/or $\geq 2 \times$ $10^{6} / \mathrm{kg} \mathrm{CD34+}$ cells in three consecutive harvestrations. Although Auto PBSC set was used in $65.9 \%$ autologous and $77.3 \%$ allogeneic donors, significantly larger number of MNC and CD34+ cells was collected with WBC set. There was a statistically significant correlation between the total number of 
collected MNC in autologous donors and baseline platelet count, the number of cycles in one apheresis procedure, quantity of collected graft and the number of MNC and CD34+ cells on the first day of harvestration (Table 5).

Table 5: Correlation between investigated parameters and total number of collected MNC in autologous donors

\begin{tabular}{|c|c|c|c|}
\hline $\begin{array}{l}\text { Total number of collected MNC Autologous } \\
\text { donors }\end{array}$ & Spearman & $t(\mathrm{~N}-2)$ & p-level \\
\hline Age & 0.091901 & 0.86577 & 0.388968 \\
\hline Body weight/kg & -0.023559 & -0.22106 & 0.825556 \\
\hline Mobilization strategy & -0.071293 & -0.67049 & 0.504300 \\
\hline Day of mobilization/beginning of harvestration & -0.014276 & -0.13393 & 0.893762 \\
\hline Baseline $\mathrm{Hgb}(\mathrm{g} / \mathrm{dl})$ & 0.007265 & 0.06816 & 0.945814 \\
\hline Baseline WBC $\left(10^{y} /\right)$ & 0.175445 & 1.67175 & 0.098126 \\
\hline Baseline Plt $\left(10^{9} / \mathrm{l}\right)$ & 0.230993 & 2.22714 & $0.028490^{*}$ \\
\hline Preapheresis WBC $\left(10^{y} / \mathrm{l}\right)$ & 0.164005 & 1.55962 & 0.122438 \\
\hline Preapheresis Hct (\%) & -0.024281 & -0.22785 & 0.820294 \\
\hline Preapheresis $\mathrm{Hgb}(\mathrm{g} / \mathrm{dl})$ & 0.008486 & 0.07961 & 0.936732 \\
\hline Preapheresis RBC $\left(10^{9} / \mathrm{l}\right)$ & 0.053234 & 0.50009 & 0.618258 \\
\hline Preapheresis Plt $\left(10^{9} / \mathrm{l}\right)$ & 0.169979 & 1.61809 & 0.109222 \\
\hline Preapheresis Lymphocytes (\%) & 0.105166 & 0.99204 & 0.323896 \\
\hline Preapheresis Monocytes (\%) & 0.126103 & 1.19247 & 0.236283 \\
\hline Preapheresis LymMon (\%) & 0.124428 & 1.17638 & 0.242616 \\
\hline Type of set for apheresis & 0.203019 & 1.94499 & 0.054969 \\
\hline Total blood volume & -0.045936 & -0.43137 & 0.667251 \\
\hline Number of apheresis procedures & -0.158539 & -1.50628 & 0.135576 \\
\hline Number of cycles in one apheresis procedure & 0.304611 & 3.00007 & $0.003510^{*}$ \\
\hline Duration of harvestration (min) & 0.083736 & 0.78829 & 0.432648 \\
\hline Processed blood (ml) & -0.014854 & -0.13935 & 0.889489 \\
\hline Used ACD-A (ml) & 0.054621 & 0.51316 & 0.609128 \\
\hline Quantity of collected graft (ml) & 0.270566 & 2.63647 & $0.009902^{*}$ \\
\hline MNC $\left(\times 10^{8} / \mathrm{kg}\right)-1^{\text {st }}$ apheresis yield & 0.524850 & 5.78426 & $0.000000^{*}$ \\
\hline CD $34+\left(\times 10^{6} / \mathrm{kg}\right)$ cells $-1^{\text {st }}$ apheresis yield & 0.383858 & 3.89966 & $0.000188^{*}$ \\
\hline Diagnosis & 0.139693 & 1.32342 & 0.189125 \\
\hline
\end{tabular}

There was a statistically significant correlation between the total number of collected MNC in allogeneic donors and baseline platelet count, the number of cycles in one apheresis procedure, quantity of collected graft and the number of collected MNC on the first day of harvestration (Table 6).

Table 6: Correlation between investigated parameters and tota number of collected MNC in allogeneic donors

\begin{tabular}{|c|c|c|c|}
\hline $\begin{array}{l}\text { Total number of collected MNC } \\
\text { Allogeneic donors }\end{array}$ & Spearman & $\mathrm{T}(\mathrm{N}-2)$ & p-level \\
\hline Age & 0.138293 & 0.73888 & 0.466130 \\
\hline Body weight - donor & -0.284884 & -1.57263 & 0.127037 \\
\hline Body weight - recipient & -0.113395 & -0.60393 & 0.550755 \\
\hline $\begin{array}{l}\text { Day of mobilization/beginning of } \\
\text { harvestration }\end{array}$ & -0.040943 & -0.21683 & 0.829910 \\
\hline Baseline Hgb (g/dl) & -0.188177 & -1.01385 & 0.319334 \\
\hline Baseline WBC $\left(10^{y} / l\right)$ & 0.053765 & 0.28491 & 0.777811 \\
\hline Baseline PIt $\left(10^{9} /\right)$ & 0.366233 & 2.08261 & $0.046539 \star$ \\
\hline Preapheresis WBC $\left(10^{9} / l\right)$ & 0.036352 & 0.19248 & 0.848754 \\
\hline Preapheresis Hct (\%) & -0.211665 & -1.14599 & 0.261498 \\
\hline Preapheresis Hgb (g/dl) & -0.077438 & -0.41100 & 0.684202 \\
\hline Preapheresis RBC $\left(10^{9} / \mathrm{I}\right)$ & -0.290003 & -1.60346 & 0.120056 \\
\hline Preapheresis Plt $\left(10^{9} / \mathrm{l}\right)$ & 0.337906 & 1.89978 & 0.067807 \\
\hline Preapheresis Lym (\%) & -0.013612 & -0.07203 & 0.943088 \\
\hline Preapheresis Mon (\%) & -0.029668 & -0.15706 & 0.876328 \\
\hline Preapheresis LymMon (\%) & -0.106831 & -0.56855 & 0.574193 \\
\hline Total blood volume (ml) & -0.234613 & -1.27710 & 0.212057 \\
\hline Number of apheresis procedures & 0.100588 & 0.53498 & 0.596890 \\
\hline $\begin{array}{l}\text { Number of cycles in one apheresis } \\
\text { procedure }\end{array}$ & 0.422963 & 2.46992 & $0.019873^{\star}$ \\
\hline Duration of harvestration (min) & 0.174423 & 0.93733 & 0.356606 \\
\hline Processed blood $(\mathrm{ml})$ & 0.009368 & 0.04957 & 0.960816 \\
\hline Used ACD-A (ml) & 0.066719 & 0.35383 & 0.726115 \\
\hline Quantity of collected graft ( $\mathrm{ml}$ ) & 0.522832 & 3.24548 & $0.003034^{\star}$ \\
\hline Adverse reactions & 0.007790 & 0.04122 & 0.967412 \\
\hline MNC $\left(\times 10^{\mathrm{z}} / \mathrm{kg}\right)-1^{\text {st }}$ apheresis yield & 0.403175 & 2.33128 & $0.027162^{\star}$ \\
\hline CD34+ $\left(x 10^{6} / \mathrm{kg}\right)$ cells $-1^{\text {st }}$ apheresis yield & 0.208007 & 1.12528 & 0.270022 \\
\hline
\end{tabular}

There was a strong correlation between the number of collected MNC and CD34+ cells on the first day of harvestration and the total number of collected MNC and CD34+ cells in poor mobilizers, and inverse correlation with the number of apheresis procedures. Donors that donated MNC $\leq 0.7 \times 10^{8} / \mathrm{kg}$ and $/$ or $\leq 0.7$

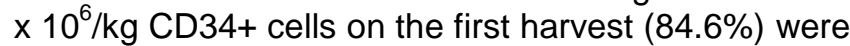

strong predictors of poor mobilizers.

\section{Discussion}

There has been a lot of investigations of predictive factors that could influence mobilization and collection of PBSC in order to improve efficacy and safety of mobilization and harvestration [19-27]. There are still a lot of contradictory in the different studies that work on this issue and final conclusions cannot be made, primarily because of heterogeneity of the donors. Baseline platelet count, the number of apheresis cycles, quantity of collected graft and the number of collected MNC and/or CD34+ cells on the first day of apheresis were predictive factors for successful HSC collection in our study in both, autologous and allogeneic donors. These findings are with consistence with our previously published study [28]. Similar to our results, Suzuya et al. [4] found out that younger age, low body mass index, a high leukocyte count before mobilization, a high platelet count before and during mobilization and a low speed of withdrawal were associated with higher CD34+ cell yield in allogeneic donors. Corso et al. demonstrated that WBC count and platelet count correlated significantly with the number of CD34+ stem cell harvested [29]. Collection of stem cells based on the rising WBC and platelet count increases the number of CD34+ cells in leukapheresis product in comparison to collection on fixed day as shown by Krieger et al. [30]. Leucocyte count was the best predictor of collection efficacy of CD34+ cells in the studies of Ford et al. [31] and Verlinden et al [32], too. Ketterer et al. [33] reported that a platelet value higher than $150 \times 10^{9} /$ correlated significantly with successful mobilization in patients with lymphoid malignancies. Zubair et al. showed that platelet count before growth factor administration significantly correlated with the total CD34+ cell yield (Spearman $r=0.38$, $p<0.001$ ). With a multiple linear regression model (adjusted R2 = 0.31 , AIC $=63.1$ ), it has been determined that the baseline platelet count significantly correlated with total CD34+ cell yield in treated plasma cell disorder patients in their study [19]. Although there was no significant association between CD34+ cell $\times 10^{6} / \mathrm{kg}$ and blood parameters in the study of Garicoa et al., they found out that leukocyte count higher than $30 \times$ $10^{9} / \mathrm{L}$ and monocyte count higher than $1.8 \times 10^{9} / \mathrm{L}$ could be predictive factors of efficient collection. However, these values cannot be considered absolute factors because patients with lower counts also had satisfactory collections [20]. Likewise to our study, some studies suggested $[34,35]$ that there was no correlation between the hematocrit and the wanted number of HSC, while another study showed inverse correlation between the two parameters [31]. Study of Mehta et al. [35], although did not show correlation between the wanted number of HSC and hematocrit in 
autologous donors, pointed out that it would be favorable harvestration to start when hematocrit is at least $25-30 \%$. Autologous donors are often anemic and there is a need for transfusion of blood components before harvestration, which is frequently the case with the platelets too, if their number is less than $30 \times 10^{9} / \mathrm{L}$ [2]. Mobilizing strategy and the number of prior cytotoxic chemotherapy cycles had been reported to adversely affect the yield of PBSC in autologous donors in our [28] and some other studies [31, 36-38]. There had been a lot of other factors that had been investigated and similar results had been revealed. These investigations included gender [31, 34], disease stadium [31], chemotherapy regimen [31], invasion of disease in bone marrow [31, 39], use of alkylating agents [40] and etc. Factors influencing apheresis procedure were investigated as well. Our study showed that the number of cycles in one apheresis procedure in autologous and allogeneic donors, and the type of set used in apheresis procedure in autologous donors, significantly influenced the collection of MNC and CD34+ cells. Zenga et al. [41] showed that number of collected MNC was positively correlated with the use of Auto PBSC set, while number of CD34+ cells was positively correlated with the use of WBC set in allogeneic donors. In other study [42], WBC set was superior to Auto PBSC set for collection of HSC in patients with multiple myeloma mobilized with G-CSF+ chemotherapy. One of the factors that did not show association with collection efficacy in our study, but had been presented in other studies as significant was processed volume of blood during apheresis [32, 34]. Ikeda et al. [39] found out in their study that mobilizing cytokines, timing of apheresis, characteristics of cellular separator and operative software influenced collection of HSC in autologous and allogeneic donors, while donor's age and gender influenced the number of collected HSC in allogeneic donors. Pastore et al. showed that lower number of CD34+ cells on the first day of collection correlated with poor mobilizers in acute leukemia patients [36]. Donors that donated MNC $\leq 0.7 \times 10^{8} / \mathrm{kg}$ and $/$ or $\leq 0.7 \times 10^{6} / \mathrm{kg}$ CD34+ cells on the first day of apheresis were strong predictors of poor mobilizers (84.6\%) in our study. Similarly to our findings Duong et al. determined a cut point of $\leq 0.7 \times 10^{6} / \mathrm{kg} \mathrm{CD34+} \mathrm{cells} \mathrm{for} \mathrm{the} \mathrm{first} \mathrm{day} \mathrm{of}$ apheresis as a predictor of inadequate CD34+ collection [43]. Early precise prediction of the likelihood of achieving adequate stem cell collection in autologous and allogeneic donors could prevent unsuccessful apheresis and permit appropriate mobilization alteration intended to improve collection of HSC.

In conclusion, baseline platelet count might be considered as an accurate indicator of PBSC mobilization and collection in autologous and allogeneic donors. However, further studies should be conducted, including a larger number of donors in each group. Determining the proper level of preaheresis laboratory parameters for initiating mobilization and apheresis procedure which is safe for donors and greatly efficient in collection of PBSC is needed for optimization of these procedures, as well as for early intervention in poor mobilizers.

\section{References}

1. Copelan EA. Hematopoietic stem-cell transplantation. N Engl J Med 2006; 354(17):1813-1826. https://doi.org/10.1056/NEJMra052638 PMid: 16641398

2. Mijovic A, Pamphlon D. Harvesting, processing and inventory management of peripheral blood stem cells. Asian J Transf Sci. 2006; 1(1): 16-23. https://doi.org/10.4103/0973-6247.28068 PMid:21938228 PMCid:PMC3168129

3. Grubovikj RM, Alavi A, Koppel A, Territo M, Schiller GJ. Minimal Residual Disease as a Predictive Factor for Relapse after Allogeneic Hematopoietic Stem Cell Transplant in Adult Patients with Acute Myeloid Leukemia in First and Second Complete Remission. Cancers. 2012; 4(2): 601-617. https://doi.org/10.3390/cancers4020601 PMid:24213327 PMCid:PMC3712693

4. Suzuya $H$, Watanabe $T$, Nakagawa $R$, Watanabe $H$, Okamoto $Y$ Onishi $\mathrm{T}$, et al. Factors associated with granulocyte colony-stimulating factor-induced peripheral blood stem cell yield in healthy donors. Vox Sang. 2005; 89: 229-235. https://doi.org/10.1111/i.14230410.2005.00701.x PMid:16262756

5. Sureda A, Bader P, Cesaro S, Dreger P, Duarte RF, Dufour C et al. for the European Society for Blood and Marrow Transplantation. Indications for allo- and auto-SCT for haematological diseases, solid tumours and immune disorders: current practice in Europe, 2015. Bone Marrow Transplant. 2015; 50: 1037-1056.

https://doi.org/10.1038/bmt.2015.6 PMid:25798672

6. Majhail NS, Farnia SH, Carpenter PA, Champlin RE, Crawford S, Marks DI et al. Indications for Autologous and Allogeneic Hematopoietic Cell Transplantation: Guidelines from the American Society for Blood and Marrow Transplantation. Biol Blood Marrow Transplant. 2015; 21(11): 1863-1869. https://doi.org/10.1016/..bbmt.2015.07.032 PMid:26256941 PMCid:PMC4830270

7. EBMT - European Group for Blood and Bone Marrow Transplantation. Annual Report 2016, available at: www.ebmt.org 8. Pasquini MC, Wang Z. Current use and outcome of hematopoietic stem cell transplantation: CIBMTR Summary Slides, 2016. CIBMTRCenter for International Bone Marrow Transplantation Research, available at: http://www.cibmtr.org

9. Grathwohl A, Schwendener A, Baldomero H, Gratwohl M, Apperley $J$, Niederwieser D et al. Changes in the use of hematopoietic stem cell transplantation: a model for diffusion of medical technology.

Haematologica. 2010; 95(4): 637-643.

https://doi.org/10.3324/haematol.2009.015586 PMid:20378578 PMCid:PMC2857194

10. Grubovic R, Georgievski B, Cevreska L, Genadieva Stavric S, Grubovic M. Evaluation of factors that influence hematopoietic recovery in patients transplanted with peripheral blood derived stem cells. Bilt Transfuziol. 2016;62(1-2):29-37.

11. Champlin RE, Schmitz N, Horowitz MM, Chapuis B, Chopra R, Cornelissen JJ, et al. Blood stem cells compared with bone marrow as a source of hematopoietic cells for allogeneic transportation. Blood. 2000;95:3702-3709. PMid:10845900

12. Gonclves TL, Benvegnu DM, Bonfanti G. Specific factors influence the success of autologous and allogeneic hematopoietic stem cell transplantation. Oxid Med Cell Longev. 2009; 2(2): 82-87. https://doi.org/10.4161/oxim.2.2.8355

13. Grubovic R, Georgievski B, Cevreska L, Genadieva Stavric S, Grubovic M. Analysis of factors that influence hematopoietic recovery in autologous transplanted patients with hematopoietic stem cells from peripheral blood. Open Access Maced J Med Sci. 2017; 5(3):324-331. https://doi.org/10.3889/oamjms.2017.039

14. Takeyama K, Ohto H. PBSC mobilization. Transfus Apher Sci. 2004;31(3):233-243. https://doi.org/10.1016/j.transci.2004.09.007 PMid:15556471

15. Pusic I, Jiang SY, Landua S, Uy GL, Rettig MP, Cashen AF, et al. 
Impact of mobilization and remobilization strategies on achieving sufficient stem cell yields for autologous transplantation. Biol Blood Marrow Transplant. 2008;14(9):1045-1056.

https://doi.org/10.1016/i.bbmt.2008.07.004 PMid:18721768

16. Schulz C, von Andrian UH, Massberg S. Hematopoietic stem and progenitor cells: their mobilization and homing to bone marrow and peripheral tissue. Immunol Res. 2009;44 (1-3):160-168. https://doi.org/10.1007/s12026-009-8109-6 PMid:19340403

17. Reddy RL. Mobilization and collection of peripheral blood progenitor cells for transplantation. Transfus Apher Sci. 2005;32(1):63-72. https://doi.org/10.1016/j.transci.2004.10.007 PMid:15737875

18. Moog R. Mobilization and harvesting of peripheral blood stem cells. Curr Stem Cell Res Ther. 2006;1(2):189-201.

https://doi.org/10.2174/157488806776956869 PMid:18220866

19. Zubair AC, Grant R, Wu W, Tun H, Rivera C, Moreno-Aspitia A, et al. Platelet count is a sensitive predictor of autologous peripheral blood progenitor cell collection yield in previously treated plasma cell disease patients. Transfusion. 2008;48:1106-1114.

https://doi.org/10.1111/j.1537-2995.2008.01651.x PMid:18315528 PMCid:PMC3919131

20. Garicoa MP, Farias MG, Junior CG. Analysis of predictive factors of complete blood count for high-yield hematopoietic stem cell apheresis collection. J Mol Pathophysiol. 2014; 3(4): 47-51. https://doi.org/10.5455/imp.20141221030312

21. Hansson M, Svensson A, Engervall P, Björkholm M, Gruber A, Soderstrom T. Increase of monocytes predicts mobilization of peripheral stem and progenitor cells after chemotherapy followed by GCSF administration. Eur J Haematol. 1995;54:321-328. https://doi.org/10.1111/j.1600-0609.1995.tb00693.x PMid:7540148 22. Kozuka T, Ikeda K, Teshima T, Kojima K, Matsuo K, Bessho A, et al. Predictive value of circulating immature cell counts in peripheral blood for timing of peripheral blood cell collection after G-CSF plus chemotherapy-induced mobilization. Transfusion 2002; 42:1514-1522. https://doi.org/10.1046/.1537-2995.2002.00218.x PMid:12421227

23. Sinha S, Gastineau D, Micallef I, Hogan W, Ansell S, Buadi F, et al. Predicting PBSC harvest failure using circulating CD34 levels: Developing target-based cutoff points for early intervention. Bone Marrow Transplant. 2011;46:943-949.

https://doi.org/10.1038/bmt.2010.236 PMid:20935680

PMCid:PMC3021104

24. Ford CD, Chan KJ, Reilly WF, Petersen FB. An evaluation of predictive factors for CD34+ cell harvest yields from patients mobilized with chemotherapy and growth factors. Transfusion. 2003;43(5):622 625. https://doi.org/10.1046/j.1537-2995.2003.00376.x PMid:12702184

25. Kudo Y, Minegishi M, Saito N, Itoh T, Fushimi J, Takahashi $\mathrm{H}$ et al The absolute number of peripheral blood CD34+ cells predicts a timing for apheresis and progenitor cell yield in patients with hematologic malignancies and solid tumors. Tohoku J Exp Med. 2003;199(2):111118. https://doi.org/10.1620/tjem.199.111 PMid:12705355

26. Makar RS, Padmanabhan A, Kim HC, Anderson C, Sugrue MW, Linenberger M. Use of laboratory tests to guide initiation of autologous hematopoietic progenitor cell collection by apheresis: results from the multicenter hematopoietic progenitor cell collection by Apheresis Laboratory Trigger Survey. Transfus Med Rev. 2014;28(4):198-204. https://doi.org/10.1016/i.tmrv.2014.08.002 PMid:25311468

27. Lysak D, Koza V, Jindra P. Factors affecting PBSC mobilization and collection in healthy donors. Transfusion and Apheresis Science. 2005;33(3): 275-83. https://doi.org/10.1016/j.transci.2005.07.007 PMid:16209935

28. Grubovic Rastvorceva R, Georgievski B, Cevreska L, Grubovic M, Genadieva Stavric Sonja, et al. Donors and apheresis characteristics that influence collection efficiency of peripheral blood hematopoietic stem cells. IMJ Medicus. 2017;22(1): 39-49.

29. Corso A, Caberlon S, Pagnucco G, Klersy C, Zappasodi P Alessandrino EP, et al. Blood stem cell collections in multiple myeloma: definition of a scoring system. Bone Marrow Transplant. 2000; 26:283 286. https://doi.org/10.1038/sj.bmt.1702514 PMid:10967566

30. Krieger MS, Schiller G, Berenson JR et al. Collection of peripheral blood progenitor cells (PBSC) based on a rising WBC and platelet count significantly increases the number of CD34+ cells. Bone Marrow Transplant. 1996; 18:1-7.

31. Ford CD, Pace N, Lehman C. Factors affecting the efficiency of collection of CD34-positive peripheral blood cells by a blood cell separator. Transfusion. 1998;38:1046-50.

https://doi.org/10.1046/i.1537-2995.1998.38111299056315.x PMid:9838936

32. Verlinden A, Van de Velde A, Verpooten GA, Janssen van Doorn K Determining factors predictive of CD34+ cell collection efficiency in an effort to avoid extended and repeated apheresis sessions. J Clin Apher. 2013;28(6):404-10. https://doi.org/10.1002/jca.21292 PMid:24038114

33. Ketterer N, Sales G, Moullet I et al. Factors associated with successful mobilization of peripheral blood progenitor cells in 200 patients with lymphoid malignancies. Br J Haematol. 1998; 103:235242. https://doi.org/10.1046/.1365-2141.1998.00960.x PMid:9792315

34. Sarkodee-Adoo C, Taran I, Guo C, Buadi F, Murthy R, Cox E, et al. Influence of preapheresis clinical factors on the efficiency of CD34+ cell collection by large-volume apheresis. Bone Marrow Transplant. 2003;31:851-5. https://doi.org/10.1038/si.bmt.1704034 PMid:12748660

35. Mehta J, Oyama Y, Winter J, Williams S, Tallman M, Singhal S, et al. CD34(+) cell collection efficiency does not correlate with the preleukapheresis hematocrit. Bone Marrow Transplant. 2001;28:597-601. https://doi.org/10.1038/sj.bmt.1703197 PMid:11607773

36. Pastore D, Specchia G, Mestice A, Liso A, Pannunzio A, Carluccio $P$, et al. Good and poor CD34+ cells mobilization in acute leukemia: analysis of factors affecting the yield of progenitor cells. Bone Marrow Transplant. 2004; 33: 1083-1087.

https://doi.org/10.1038/sj.bmt.1704437 PMid:15077126

37. Besinger W, Appelbaum F, Rowley S et al. Factors that influence collection and engraftment of autologous peripheral blood stem cells. $J$ Clin Oncol. 1997; 15: 535-546.

38. Moskowitz $\mathrm{CH}$, Glasmann GR, Wuest D, et al. Factors affecting mobilization of peripheral blood progenitor cells in patients with lymphoma. Clin Cancer Res. 1998: 4: 311-316. PMid:9516916 39. Ikeda K, Kozuka T, Harada M. Factors for PBPC collection efficiency and collection predictors. Transfus Apher Sci. 2004; 31(3):245-59. https://doi.org/10.1016/..transci.2004.09.008 PMid:15556472

40. Wuchter P, Ran D, Bruckner T, Schmitt T, Witzens-Harig M, Neben $\mathrm{K}$ et al. Mobilization of Hematopoietic Stem Cells-Definitions, Incidence, Risk Factors, and Impact on Outcome of Autologous Transplantation. Biol Blood Marrow Transplant. 2010;16: 490-99. https://doi.org/10.1016/i.bbmt.2009.11.012 PMid:19925876

41. Zeng F, Wei SJ, Huang HB, Huang QH, Lin QY, Fan LP et al. Analysis of the efficiency and influence factors of PBSC collection with Auto PBSC and MNC procedure of cell separator. Zhongguo Shi Yan Xue Ye Xue Za Zhi. 2014;22(6):1684-90. PMid:25543497

42. Cooling L, Hoffmann S, Herrst M, Muck C, Armelagos H, Davenport R. A prospective randomized trial of two popular mononuclear cell collection sets for autologous peripheral blood stem cell collection in multiple myeloma. Transfusion. 2010;50(1):100-19. https://doi.org/10.1111//.1537-2995.2009.02350.x PMid:19719472

43. Duong H, Bolwell B, Rybicki L, Koo A, His E, Figueroa P, et al. Predicting hematopoietic stem cell mobilization failure in patients with multiple myeloma: a simple method using day 1 CD34+ cell yield. $\mathrm{J}$ Clin Apher. 2011; 26:111-115. https://doi.org/10.1002/jca.20278

PMid:21647951 